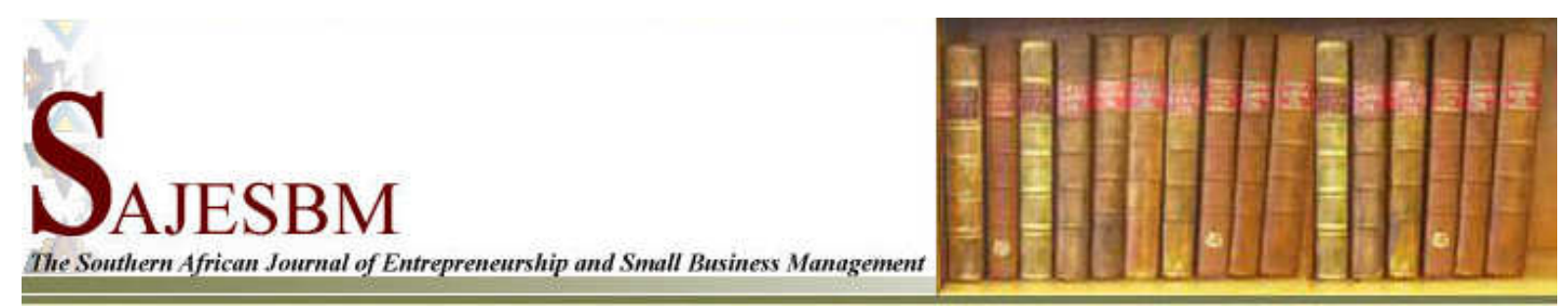

www.sajesbm.com

\title{
Logistics benefits and challenges: the case of SMEs in a South African local municipality
}

\author{
Chengedzai MAFINI* \\ Department of Logistics \\ Vaal University of Technology \\ Osayuwamen OMORUYI \\ Department of Logistics \\ Vaal University of Technology
}

\begin{abstract}
* Corresponding author
Department of Logistics,

Vaal University of Technology

P.Bag X021 Vanderbijlpark, 1900

chengedzai@hotmail.com
\end{abstract}

\begin{abstract}
Small and medium enterprises (SMEs) are the lifeblood of every economy. However, in order for them to sustain their role of contributing to the mainstream economy, SMEs have to implement effective strategies in all of their business operations, inclusive of logistics. The function of logistics is important to SMEs because it is the quintessence of the organisation's relationship with suppliers and customers. The aim of this study was to investigate the challenges encountered as well as the benefits realised by SMEs during the implementation of logistics strategies. A quantitative approach using the cross-sectional descriptive survey technique was used in which a three-section questionnaire was administered to a randomly selected sample of 131 SME owners and managers in Emfuleni Local Municipality in Gauteng Province, South Africa. Data analysis was conducted using simple descriptive statistics. The results of the study reveal that financial constraints, the lack of logistics skills among the workforce, high costs of information technology and rapid technological advancements were the most important challenges to SMEs. Challenges related to inventory and environmental management emerged as the least relevant. Enhanced competitive advantage, increased sales and a reduction in operational costs were the most important benefits to SMEs. Reduction in labour turnover and innovation emerged as the least important benefits. Based on the findings, several recommendations were proposed.
\end{abstract}

Key Words: SME, benefits, challenges, Emfuleni Local Municipality

\section{INTRODUCTION AND BACKGROUND TO THE STUDY}

In recent times, small to medium enterprises (SMEs) have become a topical subject among management and research practitioners the world over. This has lead to a proliferation of 
research interests centred on SMEs. In the context of business research, a number of studies (Pittaway \& Morrissey, 2004; Ellegaard, 2006; Hendrickson, 2009; Gourova, 2010; Chin, Hamid, Rasli \& Baharun, 2012) have focused on business practices and strategies that SMEs could adopt for both competitive advantage as well as survival in the challenging and dynamic global operational environment. The function of logistics has become known as an important instrument in contemporary business practice, because it is available for manipulation by all business enterprises, inclusive of SMEs.

Despite the fact that the practicality of logistics is evident in its involvement in everyday life, most SMEs often consider logistics strategy either as an addendum to overall strategy formation or as a strategy that is implemented exclusively by large organisations (Lukka, 2005). This perspective is erroneous because it has been proved that logistics performs a strategic role to both SMEs and large enterprises (Levey \& Powell, 2005). Logistics has become so essential to an extent that SMEs that are planning to build a corporate perspective of the future without recognising the importance of logistics as a strategic focus may only be engaged in wishful thinking (Drew \& Smith, 1998).

The implementation of logistics strategies by SMEs is associated with a family of indispensible paybacks that may be realised, which are important for both short and long term success (Narasimhan \& Talluri, 2009). However, no process or strategy, regardless of the benefits associated with its adoption, is immune to challenges (Hagen, Zucchella, Cerchiello \& De Giovanni, 2012). The same principle holds true for the adoption of logistics strategies by SMEs. SMEs are often inundated with a multiplicity of logistics challenges in their day to day operations (Polychronakis \& $\mathrm{Li}, 2008$ ). It is expedient then that both these challenges as well as benefits are subjected to empirical introspection on a perpetual basis. An updated expose' of these challenges will create opportunities for current and appropriate solutions to be found and for the benefits associated with the optimisation of logistics strategies to be realised.

\section{AIMS OF THE STUDY}

The purpose of this study is twofold. First the study aims to investigate the benefits of implementing logistics strategies in SMEs. Second, the study aims to investigate the challenges that SMEs face in adopting and implementing logistics strategies. The study was conducted using SMES that are located in Emfuleni Local Municipality in Gauteng Province, South Africa. Emfuleni Local Municipality covers areas such as Evaton, Sharpville, Sebokeng, Bophelong, Polokong, Vereeniging and Vanderbijlpark.

\section{STRUCTURE OF THE PAPER}

This paper is structured as follows: the paper will first discuss the literature review covering four areas that are important in this study, namely logistics strategies, SMEs, logistics benefits and logistics challenges. This will be followed by the methodology section, which will specify the modalities that were implemented in conducting the study. The methodology section will be succeeded by the results and discussion section where the outcomes of the study will be highlighted. Conclusions and recommendations as well as the limitations of the study and the implications for further research will occupy the final sections of the paper.

\section{LITERATURE REVIEW}

\section{Logistics}

Widely regarded as the backbone of any company, the function of Logistics Management encompasses an assemblage of organisational disciplines that include material planning and handling, transportation, procurement, warehousing and information systems that allow goods and services to overcome time and space (Gentle, 2008). It may also be perceived as the process of planning and implementing the flow of products, parts, services and

www.sajesbm.com

Article no 166 
related information necessary for production and delivery (Lasserre, 2004). Logistics has an important theoretical and conceptual foundation, drawing on theories from a range of disciplines such as marketing, purchasing and supply, business strategy, supply-chain management (SCM), economics, organisational theory as well as general management (Dekker, Bloemhof \& Mallidis, 2012). Therefore, a clear understanding of the company's culture and the value logistics places on these disciplines as well as the processes and management style necessary in dealing with them will lead to manifold benefits for the organisation (Escriba-Esteve, Sanchez-Peinado \& Sanchez-Peinado, 2009).

As a strategic management activity in an organisation, logistics can have a phenomenal impact on the operational, market and financial performance of the organisation (Narasimhan \& Talluri, 2009). Several authors (Bienstock, Royne, Sherrell \& Stafford, 2007; Koskinen \& Hilmola, 2008) suggest that logistics is a necessary cornerstone of a competitive strategy for organisations that strive to keep pace with market changes, increased market share and shareholder value. Generally, logistics is regarded as a strategy to keep pace with competitors, market changes and supply-chain integration (Meade \& Sarkis, 1998). It also enables companies to be more flexible and responsive in order to cope with changes in the internal and external environment (Zhang, Vonderembse \& Su Lim, 2005). The drive for greater efficiencies and cost reductions has forced many organisations to specialise in a limited number of key areas, such that most logistics strategies have been outsourced by large organisations as a strategy to improve performance and reduce costs (Mclvor, 2006). Logistics strategy is among the major reasons for the existence of an enterprise, the thread that connects the enterprise and its customers and helps the organisation to stay alert in order to survive in striving for business success in today's unpredictable operating environment (Chopra \& Meindl, 2010).

Logistics may also be conceptualised within the rubric of the value in the form of products and services that that it creates for companies and delivers into the hands of the ultimate customers (Christopher, 1998; Mckinnon, 2009). In this context, logistics creates additional value and brings capital into the organisation to enhance the product life-cycle for continuous improvement and product development because the key for an organisation's success is that more money as well as capital should flow into the organisation than flows out (Kruse, 2007). However, this can only be realised if logistics strategies are carefully initiated, developed and implemented (Benjaafar, Li \& Daskin, 2010). It appears then, that organisational efficiency and performance can be enhanced if logistics strategy is considered as an important business approach in the organisation.

\section{Small to Medium Enterprises (SMEs)}

There is no single universally accepted definition of SMEs (Hamisi, 2011). Instead, definitions for the concept vary from country to country (Hill \& Wright, 2001). Consequently, there has been an avalanche of conceptualisations from a wide spectrum of authors (e.g. Simpson \& Docherty, 2004; Deros, Yusof \& Salleh, 2006; Mutula \& Brakel, 2006). However, for the purposes of this study SMEs can be perceived as the efficient motor of every market economy that is differentiated from large enterprises as having a maximum of R40 million annual turnover, a minimum of 75 percent of company assets owned by company manager, owner-manager or their families who manage the company personally, and a maximum of R27 million balance-sheet total (Loecger, 2000). SMEs are further sub-divided according to the number of employees e.g. 0-50 employees for small companies, 50-250 employees for medium companies and more than 250 employees for large companies (Loecger, 2000; Falkena, 2000).

SMEs originate from entrepreneurial individuals, who identify new opportunities in society and who are motivated to exploit such opportunities (Burke, 2006). Therefore, in terms of

www.sajesbm.com

Article no 166 
their characteristics, SMEs are also analogous to the entrepreneurial new venture, especially in areas such as risk taking, flexibility, innovation/creativity hands-on management (Ellegaard, 2006).

A number of researchers (Rogerson, 2000; Ruiz-Santos, Ruiz-Mercader \& McDonald, 2003; O'regan \& Ghobadian, 2004; Simpson \& Docherty, 2004; Pasanen \& Laukkanen, 2006; Oke, Burke \& Myers, 2007; Chiware \& Dick, 2008) acknowledge that despite their restriction in terms of the number of employees, annual sales and balance sheet, the role of SMEs in facilitating economic development, alleviating poverty, increasing employment and providing and supplying various items of daily use at an affordable cost to both consumers and large enterprises (LEs) of any country is of exceptional significance. For example, in South Africa SMEs constitute 95 per cent of the total business of both the formal and informal sectors (Soontiens, 2002). SMEs also create substantial job opportunities, help narrow the gap between urban and rural development, alleviate poverty, and as well employ more people per unit of investment as compared to large firms (Zelealem \& Pansiri, 2006). Moreover, SMEs are the source of new ideas, materials, processes and services, that larger organisations are unable to provide (Chen, 1999). This demonstrates that SMEs are an important driver of economic growth in South Africa, which has compelled government, cooperate bodies, and institutions to exert more emphasis on innovative SMEs research and development (Oke et al., 2007; Nielsen \& Thomsen, 2009).

SMEs are also renowned for their fast decision-making, on-time availability of goods and services/raw material and innovative products which cater for the needs of the individual in the economy, flexible personalised services and a speedy response to changing market demands (Karjalainen \& Kemppainen, 2008). In support, Raymond and Croteau (2006) underscore that SMEs have advantages in terms of flexibility, reaction time and innovation capacity that make them central actors in the economy. For this reason SMEs are commonly referred to as a 'building block for achieving economic development and growth' (Soontiens, 2002).

\section{The Benefits of Logistics Strategies in SMEs}

Logistics as an overarching activity is of paramount importance to SMEs because it is the essence of the organisation's relationship with the customer, who is in turn, the revenue generator for SMEs (Burt, Petcavage \& Pinkerton, 2010). It determines where the money comes from and addresses the reason for existing in business, that is, to create and profit by satisfying customers' needs (Krajewski, Ritzman \& Malhotra, 2010). Logistics strategies also provide continuous customer relationship improvement in order to gain competitive priority (Chen, 1999).

The marketer informs the customer about the product and its benefits and describes how the product could be used by the customer as well as how the customers can get the product (Fawcett, Magnan \& Mccarter, 2008). Given this impetus, the customer eventually places an order. When the customer places an order, something happens along the chain which the marketers call 'delivering on the promise, which is the responsibility of logistics (Burt et al., 2010). This implies that logistics merges the gap between the producers or suppliers, marketers and the customers (Fawcett et al., 2008). It determines whether the SME will be able to deliver the product as promised or will let the customer down (Hong \& Jeong, 2006). The way a logistics strategy is implemented by the SMEs determines their commitment to customers and profitability. Logistics is therefore important for all organisations because it makes or breaks customer relationships (Cant, Strydom, Jooste \& Du Plessis, 2006).

A study conducted by Anja, Thomas and Sascha (2009), which focused on SMEs in Germany concluded that SMEs tend to consider logistics strategy as very important, due to

www.sajesbm.com

Article no 166 
its value-added benefits and the competitive advantages it provides that lead to profit maximisation. Additionally, another study conducted by Mason, Ribera, Farris and Kirk (2003) found that SMEs in the USA seek to optimise every stage of the logistics chain to maximum value and they strive to optimise the operation of the supply chain as a whole in areas such as product delivery time, inventory holding cost, and the overall cost-to-market. This further attests to the significance of logistics to SMEs.

Logistics has emerged as a powerful source of competitive advantage to South African SMEs, especially after transportation deregulation and improvements in information technology that have enabled companies to gain competitive advantage through competence in speed delivery of customer orders, reliability, flexibility/responsiveness to changing market demands and low-cost distribution (Van der vorst, Beulens \& Van Beek 2005, Zacharia \& Mentzer, 2007). Furthermore, logistics processes can also provide a basis for a competitive profit edge through transportation and distribution activities (Agapiou, Clausen, Flanagan \& Norman, 1998; Krajewski, et al., 2010). Logistics strategies also lead to effective business process redesign, elimination of traditional barriers and a total supply chain viewpoint (Anja et al., 2009). Lesserre (2004) adds that most companies have realised that logistics is not only a way to differentiate from competitors, but also a strategy factor in maximising the value chain. Consequently, logistics strategies within SMEs are growing due to new requests from customers, ongoing improvement in internal processes and reevaluation of company logistics strategies (Levey \& Powell, 2005).

As the marketplace becomes more intense with competitive pressure, high levels of turbulence and uncertainty, SMEs require logistical capabilities to provide superior value and to manage delay and disruption to operations as well as to ensure uninterrupted service to customers (Braunscheidel \& Suresh, 2007). Generally, the emergence of logistics pertains to the development of flexibility and quick response in order to cope with challenges of more dynamic market places (Drew \& Smith, 1998). Therefore SMEs can exploit logistics strategies as a prevailing source of future value-creation and to strengthen capabilities for coping with ever-more disruptive and traumatic market developments.

\section{Challenges to SMEs Logistics Capabilities}

SMEs typically face a number of challenges such as pressure from larger competitors, the need to function independently, shortage of resources and several operational problems such as in areas of inventory management and organisational capacity. For instance, SMEs experience difficulties/challenges in their performance because supply chain integration is complex (Ebrahim, Ahmed \& Taha, 2008). The implementation of logistics strategies within SMEs is often triggered by pressure from customers or by large enterprises whose focus is on the adoption of a pull approach rather than the traditional push approach (Gelinas \& Bigras, 2004). As a result, SMEs are compelled to broaden the vision of their logistics chain strategy to refocus activities on basic skills. Because of these increasing needs in implementing logistics strategies, SMEs may experience more difficulties/challenges in implementing their logistics strategy in order to compete effectively (Thakkar, Kanda \& Deshmukh, 2008).

To be successful, SMEs must understand the importance of logistics strategy implementation, be observant and adjust to the needs of their customers to preserve their market shares and to assure their growth (Hong \& Jeong, 2006). However the need for independence and autonomy by SMEs, together with a low propensity to delegate and consult, may be obstacles to the introduction of success factors such as participatory management, the use of a decision support system, and the use of external expertise for logistics subcontracting (Gelinas \& Bigras, 2004). 
Logistics strategy demands that organisations further widen the scope of the business activities, which can become more challenging as product life-cycles shorten, product variety increases, and technological advancement proceeds at an exponential rate and there is an increase in demand for customer satisfaction (Bozarth, Donald \& Barbara, 2007). Furthermore, SMEs also lack technical manpower, research and development, finance and education, which are factors that frequently propel many SMEs into a sustained negative trajectory (Cocca \& Alberti, 2010). As a key driver of economic growth, SMEs must develop themselves strategically to be more competitive to meet domestic, international and globalisation challenges and to offer good product/service design and performance (Raymond \& Croteau, 2006). SMEs also face the challenge of using logistics strategies that play a key role in aligning business strategy such as delivery, ordering, productivity and responsiveness to customer needs (Deros et al., 2006).

Another challenge to SME logistics capabilities involves complications related to inventory management, which relate to the dilemma of holding excess inventory in order to meet high demand or to hold small volumes of inventory in order to protect the company's liquidity (Hendricks \& Singhal, 2005). In certain cases, many SMEs also struggle to ensure that the right product is available in the right quantities at operational level, as exhibited through errors and delivery problems (Hamisi, 2011). Such SMEs fail to satisfy the needs of their customers (Zeithaml, Bitner, Gremler \& Pandit, 2008). Abonyi (2005) also contends that because of their limited size and isolation, most SMEs are inhibited from attaining economies of scale in the purchase of vital inputs such as equipment, raw materials, finance, and consulting services. As a result, SMES are often unable to identify potential markets; and are incapable of exploiting existing market opportunities that require large volumes, reliable quality and acceptably high standards, and to ensure the regular supply of their products to their customers (Udin, Khan \& Zairi, 2006).

Because of limited resources, SMEs are often unable to benefit from the opportunities offered by global value chains because of their low connectivity to global transport networks and their weak productive capacity (Arvis, Mustra, Panzer, Ojala \& Naula, 2007). In the technologically oriented operational environment of today, technology-related issues and revolutions continue to inflict SMEs with poor market competitiveness, since most SMEs do not have sufficient capitalisation to adopt new technologies (Mbamba, 2009).

\section{RESEARCH METHODOLOGY}

\section{Research Approach}

In the current study, a quantitative approach using the cross-sectional descriptive survey technique was used (Creswell, 2009). In quantitative research the primary objective is to quantify the collected data and to generalise the results from the sample to the population of interest (Malhotra, 2007). The quantitative approach was selected for the current study because quantitative research enhances the objectivity of the study since it is cheap, flexible and less time-consuming to conduct (Cooper \& Schindler, 2011). The quantitative nature of the study was also based in the need to quantify the data collected and to generalise the findings (Fouche \& De Vos, 2005) in terms of the impact of Logistics strategies on SMEs in Emfuleni Local Municipality in the current study to other SMEs in South Africa and beyond.

\section{Participants}

The target population for the current study consisted of SMEs located in Emfuleni Local Municipality. The sampling frame comprised a list of 1026 registered SMEs which was accessed from the database of Emfuleni Local Municipality. For the purpose of the current study, probability sampling using the simple random sampling technique was utilised to select the sample size. Simple random sampling was selected because it is simple to apply,

www.sajesbm.com

Article no 166 
makes data analysis reasonably easy and has a sound mathematical basis (Gravetter \& Forzano 2003; Strydom 2005). The sample size was set at $n=200$, consistently with previous studies (Overby \& Servais, 2005; Zeimpekis \& Giaglis, 2006; Haan, Kisperska-Moron \& Placzek, 2007; Thakkar et al., 2008; Vaaland \& Heide, 2007) in which almost the same ranges of sample size were used to examine the benefits of logistics strategies in SMES, as illustrated in Table 1.

Table 1: Sample sizes used in previous studies

\begin{tabular}{|c|lr|l|c|}
\hline Year & \multicolumn{1}{|c|}{ Authors } & \multicolumn{1}{|c|}{ Scope of study } & $\begin{array}{c}\text { Sample size } \\
\text { used }\end{array}$ \\
\hline 2007 & $\begin{array}{l}\text { Haan } \\
\text { Kisperska- } \\
\text { Moron } \\
\text { Placzek }\end{array} \quad$ \& & $\begin{array}{l}\text { Logistics management and firm size; a survey } \\
\text { among Polish small and medium enterprises }\end{array}$ & 127 \\
\hline 2007 & $\begin{array}{l}\text { Vaaland \& \& } \\
\text { Heide }\end{array}$ & $\begin{array}{l}\text { Can the SMEs survive the supply chain } \\
\text { challenges }\end{array}$ & 200 \\
\hline 2008 & $\begin{array}{l}\text { Thakkar, } \\
\text { Kanda } \\
\text { Deshmukh \& \& }\end{array}$ & $\begin{array}{l}\text { Supply chain management in SMEs: } \\
\text { Development of constructs and propositions. }\end{array}$ & $\mathbf{7 7}$ \\
\hline 2005 & $\begin{array}{l}\text { Overby } \\
\text { Servais, \& }\end{array}$ & $\begin{array}{l}\text { Small and Medium-sized firms import behaviour: } \\
\text { The case of Danish industrial purchasers }\end{array}$ & 105 \\
\hline 2006 & $\begin{array}{l}\text { Zeimpekis \& \& } \\
\text { Giaglis }\end{array}$ & $\begin{array}{l}\text { Urban dynamics real-time distribution services: } \\
\text { Insights from SMEs. }\end{array}$ & 73 \\
\hline
\end{tabular}

\section{Instrumentation and Data Collection Techniques}

For the purposes of the current study, a three section questionnaire was developed. Section $A$ of the questionnaire elicited information on the demographic characteristics of the respondents as well as the profile of the SMEs. Section B elicited data on the challenges faced by SMEs in the implementation of logistics strategies. Questions used in Section B were adapted from previous studies (Fawcett et al., 2008; Hendrikson, 2009; Mbamba, 2009) which also focused on logistics related challenges faced by SMEs. Section $C$ elicited questions (adapted from Pittaway \& Morrissey, 2004; Hong \& Jeong, 2006) on the benefits realised by SMEs in the implementation of logistics strategies. Questions on Sections B and $\mathrm{C}$ were configured in a six point Likert style format anchored by ' 1 ' $=$ not important and ' 6 ' $=$ the very important. Likert scales were used because they are relatively easy to construct, make data easy to collect and analyse, thereby making them suitable for surveys (Kothari, 2008).

To ascertain content validity, which is the representativeness of the content of the measurement instrument (Malhotra, 2009) the questionnaire was pre-tested with a conveniently selected sample of thirty SMEs. Feedback from the pre-test sample was used as the basis for effecting some changes to the questionnaire. After the pre-test, the refined questionnaires were re-distributed to a different conveniently selected sample of twenty SMEs as a pilot study in order to check the reliability of the scale. The pilot study revealed that the scale had satisfactory reliability levels which ranged from 0.722 to 0.845 (Maree \& Pietersen, 2007) and that there were no further ambiguities in the questions.

A covering letter which listed the researchers' details as well as the topic and purpose of the study was attached to the questionnaire. Ethical considerations such as the participants' right to anonymity, confidentiality, privacy or non-participation, informed consent and protection from discomfort, harm and victimisation were adhered to during the administration 
of the questionnaire. Out of the 200 questionnaires that were initially distributed to SMEs, 147 were returned, giving a return rate of $74 \%$. However, after the screening process, 16 questionnaires were eliminated because they either had incomplete answers or they were answered incorrectly. This culminated in 131 questionnaires, which were used in the actual data analysis.

\section{RESEARCH RESULTS}

\section{Demographic Profile of Respondents}

The questionnaire was completed by various SME business owners and managers in Emfuleni Local Municipality. Approximately $61 \%(n=80)$ of the respondents were male and $39 \%(n=51)$ were female. In addition, a majority of the business owners/ managers $(64 \%$; $n=84)$ were aged above 30 years and the remaining $36 \%(n=47)$ were aged below 30 years. In terms of academic qualifications, $43 \%(n=56)$ of respondents were in possession of either a higher education Diploma or a Certificate; $14 \%(n=18)$ were in possession of at least a university degree and $35 \%(n=46)$ had completed matric. The later characteristic was favourable to the current study because it indicated that the literacy levels of respondents were sufficiently high, which was a reflection of their ability to understand the questions in the data collection instrument.

\section{Profiles of Businesses}

The profiles of SMEs that participated in the survey are illustrated in Table 2.

Table 2: Profile of participating SMEs

\begin{tabular}{|c|c|c|c|c|}
\hline Variable & Categories & $\mathbf{N}$ & $\mathbf{n}$ & $\%$ \\
\hline $\begin{array}{l}\text { Number of years of } \\
\text { business existence }\end{array}$ & $\begin{array}{l}\leq 4 \text { years } \\
5-7 \text { years } \\
8-10 \text { years } \\
\geq 11 \text { years }\end{array}$ & $\begin{array}{l}131 \\
131 \\
131 \\
131\end{array}$ & $\begin{array}{l}44 \\
35 \\
18 \\
34\end{array}$ & $\begin{array}{l}33.59 \\
26.72 \\
13.74 \\
25.95\end{array}$ \\
\hline Annual sales & $\begin{array}{l}\leq R 1 \text { million } \\
R 1 \text { million- } R 2 \text { million } \\
R 2 \text { million- } R 3 \text { million } \\
R 3 \text { million- } R 4 \text { million } \\
\geq R 4 \text { million }\end{array}$ & $\begin{array}{l}131 \\
131 \\
131 \\
131 \\
131\end{array}$ & $\begin{array}{c}69 \\
31 \\
13 \\
12 \\
6\end{array}$ & $\begin{array}{c}52.67 \\
23.66 \\
9.92 \\
9.16 \\
4.59\end{array}$ \\
\hline $\begin{array}{l}\text { Number } \\
\text { employees }\end{array}$ & $\begin{array}{l}\leq 50 \\
50-99 \\
100-200 \\
\geq 200\end{array}$ & $\begin{array}{l}131 \\
131 \\
131 \\
131\end{array}$ & $\begin{array}{c}82 \\
27 \\
14 \\
8\end{array}$ & $\begin{array}{c}62.60 \\
20.56 \\
10.69 \\
6.15\end{array}$ \\
\hline Type of industry & $\begin{array}{l}\text { Trading } \\
\text { Services } \\
\text { Engineering } \\
\text { Chemicals and } \\
\text { pharmaceutical } \\
\text { Electrical and electronics } \\
\text { Building and materials } \\
\text { Wood and furniture } \\
\text { Food and beverages } \\
\text { Other }\end{array}$ & $\begin{array}{l}131 \\
131 \\
131 \\
131 \\
131 \\
131 \\
131 \\
131 \\
131\end{array}$ & $\begin{array}{c}29 \\
10 \\
9 \\
7 \\
11 \\
12 \\
29 \\
19 \\
5\end{array}$ & $\begin{array}{c}22.14 \\
7.63 \\
6.87 \\
5.34 \\
8.87 \\
9.18 \\
21.72 \\
14.79 \\
3.46\end{array}$ \\
\hline
\end{tabular}


An analysis of the profile of SMEs that participated in the study (Refer to Table 2) indicates that approximately $60 \%(n=79)$ of the businesses had been in operation for periods less than seven years. A majority of the SMEs $(53 \% ; n=69)$ had an annual turnover of less than one million rand. Furthermore, approximately $63 \%(n=82)$ of the participating SMEs employed less than 100 people. In terms of the type of industry of the participating SMEs, the most highly represented industry sectors were trading $(22 \% ; n=29)$, wood and furniture $(22 \%$; $n=29)$ and food and beverages $(15 \% ; n=19)$.

\section{Scale Reliability}

The internal consistency of the two major scales (Sections B \& C) used in the study is reported in Table 3. The Cronbach alpha value for the logistics challenges scale was 0.722 and the Cronbach alpha value for the logistics benefits scale was 0.845 . The Cronbach alpha value for the entire scale was 0.773 . These values were all above the acceptable threshold level of 0.70 (Malhotra, 2011).

Table 3: Mean and internal consistency of scales

\begin{tabular}{lccc}
\hline Dimension description & Number of items & Mean & $\begin{array}{c}\text { Cronbach } \\
\text { alpha }\end{array}$ \\
\hline Logistics challenges & 16 & 4.729 & 0.722 \\
Logistics benefits & 27 & 4.955 & 0.845 \\
Overall scale & 43 & 4.846 & 0.773 \\
\hline
\end{tabular}

Content validity is the representativeness of the content of the measurement instrument (Malhotra, 2011). The pre-testing and piloting of the questionnaire significantly improved the content validity of the entire instrument. In addition, high alpha values were achieved in the reliability tests for the various sub-scales, thereby indicating a satisfactory level of construct validity.

\section{Logistics Challenges facing SMEs}

Table 4 illustrates the responses obtained on challenges that are faced by SMEs in implementing logistics strategies, as elicited through Section B of the questionnaire. The challenges have been placed in rank order, in accordance with the frequencies obtained.

Table 4: Challenging factors in implementing logistics strategies

\begin{tabular}{|l|l|l|l|l|l|l|l|r|}
\hline & \multicolumn{1}{|c|}{$\begin{array}{c}\text { Valid } \\
\text { Challenges }\end{array}$} & \multicolumn{1}{|c|}{ Rating of Challenges } & $\begin{array}{l}\text { Position } \\
\text { in } \\
\text { rank } \\
\text { order }\end{array}$ \\
\hline Financial constraints & 131 & 7.63 & 3.05 & 9.92 & 22.90 & 23.66 & 32.82 & 1 \\
\hline $\begin{array}{l}\text { Lack of skills/competences } \\
\text { among workforce }\end{array}$ & 131 & 6.11 & 3.82 & 13.74 & 16.03 & 28.24 & 32.06 & 2 \\
\hline $\begin{array}{l}\text { High cost of information } \\
\text { technology }\end{array}$ & 131 & 3.82 & 6.11 & 6.11 & 22.90 & 32.82 & 28.24 & 3 \\
\hline $\begin{array}{l}\text { Rapid technological } \\
\text { advancement }\end{array}$ & 131 & 6.87 & 4.58 & 6.11 & 25.19 & 24.43 & 32.82 & 4 \\
\hline $\begin{array}{l}\text { Logistics excellence among } \\
\text { competitors }\end{array}$ & 131 & 6.98 & 2.55 & 10.85 & 23.26 & 30.23 & 27.13 & 5 \\
\hline $\begin{array}{l}\text { Greater demands from order } \\
\text { givers }\end{array}$ & 131 & 5.34 & 3.05 & 16.79 & 15.27 & 28.24 & 31.30 & 6 \\
\hline $\begin{array}{l}\text { Increased use of third-party } \\
\text { logistics services }\end{array}$ & 131 & 7.69 & 5.38 & 16.92 & 26.38 & 26.92 & 17.69 & 7 \\
\hline $\begin{array}{l}\text { Competition on domestic } \\
\text { markets }\end{array}$ & 131 & 5.34 & 5.34 & 13.74 & 19.08 & 25.19 & 31.30 & 8 \\
\hline
\end{tabular}




\begin{tabular}{|c|c|c|c|c|c|c|c|c|}
\hline Increased global competition & 131 & 9.23 & 4.85 & 14.62 & 15.38 & 34.62 & 22.31 & 9 \\
\hline $\begin{array}{l}\text { Lack of quality logistics } \\
\text { personnel }\end{array}$ & 131 & 8.40 & 6.11 & 13.74 & 20.61 & 25.19 & 25.95 & 10 \\
\hline $\begin{array}{l}\text { Organisational } \\
\text { transformation }\end{array}$ & 131 & 8.40 & 3.82 & 12.21 & 25.19 & 27.48 & 22.90 & 11 \\
\hline $\begin{array}{l}\text { Refocusing of activities on } \\
\text { basic skills }\end{array}$ & 131 & 8.40 & 6.87 & 7.63 & 24.43 & 29.01 & 23.66 & 12 \\
\hline High customer expectations & 131 & 5.34 & 3.82 & 6.87 & 19.08 & 26.72 & 38.17 & 13 \\
\hline $\begin{array}{l}\text { Lack of knowledge on how to } \\
\text { use current logistical } \\
\text { techniques }\end{array}$ & 131 & 5.43 & 5.43 & 18.05 & 18.05 & 26.36 & 28.68 & 14 \\
\hline $\begin{array}{l}\text { Environmental concerns } \\
\text { (Green logistics) }\end{array}$ & 131 & 9.16 & 4.58 & 15.27 & 21.37 & 27.48 & 22.14 & 15 \\
\hline $\begin{array}{l}\text { Inventory-management } \\
\text { complications }\end{array}$ & 131 & 6.11 & 5.34 & 16.79 & 18.32 & 24.43 & 29.01 & 16 \\
\hline $\begin{array}{l}\text { Average percentage per } \\
\text { response }\end{array}$ & & 6.89 & 4.54 & 12.40 & 20.72 & 27.56 & 27.89 & \\
\hline \multicolumn{9}{|c|}{ KEY: $1=$ Not important $\quad 6=$ Very important } \\
\hline
\end{tabular}

The analysis of the results as illustrated in Table 4 yields two streams of observations. Financial constraints, the lack of skills among employees in SMEs, the high cost of information technology and rapid technological advancements emerged as the most important challenges among SMEs. At the bottom-most quadrants of the matrix were inventory management complications and environmental concerns.

Financial constraints emerged as the top ranking challenge that SMEs face in implementing logistics strategies. Consistently with this result, a task force commissioned in 2007 by the South African government to investigate modalities of financing SMEs acknowledged that a majority of SMEs are undercapitalised and are unable to obtain assistance from financial institutions because they do not have sufficient collateral (Falkena et al., 2010). Musara \& Olawale (2012) also advocate that access to finance has been singled out as one of the major challenges impeding the survival and growth of SMEs in South Africa. Consequently, the bulk of SMEs are unable to effectively implement various pivotal operational strategies which ensure their growth and sustenance (Rogerson, 2008; Talavera \& Shafer, 2008). Since logistics strategies are fundamental to the organisation (Kuthiala, 2003) it is natural that the overall failure of SMEs to acquire sufficient financial capital could have a detrimental effect to implementation of logistics strategies.

In the study, the lack of personnel who are adequately skilled to implement logistics strategies emerged as the second most important challenge. It is generally acknowledged that South Africa as a country faces a crippling shortage of skilled labour (Grant Thornton's International Business Report, 2012). The type of unemployment experienced in South Africa is termed structural unemployment, which is unemployment that is linked to a deficit in skilled manpower in certain areas that are critical to the country's economic prosperity (Chadha, 1994; Sharp, 2011). More specifically, there is a shortage of appropriately qualified skilled manpower in the supply chain industry in South Africa (Heyns \& Luke, 2012). Moreover, in situations where there is a scarcity of qualified skills, the few available skilled personnel are likely to demand higher remuneration, which can only be sustained by larger enterprises rather than SMES (Damaskopoulos \& Evgeniou, 2003). It appears then that this scenario has had a significant impact on the implementation of logistics strategies by SMEs. 
One of the main factors that influences in the success or failure of enterprise is technology. In this study, technological issues emerged as the third and fourth most important challenges facing SMEs. The best use of technology doubtlessly helps the enterprise in reducing costs of production, maintaining consistency in quality, improving productivity and to develop the competitiveness of the enterprise (Napier, Serger \& Hansson, 2004). However, the diffusion of technology into the SME sector remains a daunting challenge, all round (Nepal, Karki \& Niraula, 2006). In most developing countries, the technology used by SMEs in their operations is imported, which presents a cost-related albatross for SMEs, since they are inadequately financed to meet the expense (DTI, 2004). Furthermore, rapid technological advancements linked to logistics, such as Electronic Data Interchange (EDI), Distribution Resources Planning (DRP), Automated Storage/Retrieval Systems (AS/RS) and are capital intensive in terms of adoption (Zacharia \& Mentzer, 2004). Therefore, it is only natural that both the high cost of information technologies and the fast pace at which technology is changing have become major threats to SMEs as they implement logistics strategies.

In the study, complications related to the management of inventory emerged as the least important challenge among SMEs. This result demonstrates that SMEs perceived that inventory management has not yet posed a severe threat to their implementation of logistics strategies. To appreciate the possible reasons for this result, one needs to understand the most common cause of inventory complications. Inventory-related challenges are mostly linked to a phenomenon known as the bullwhip effect, which relates to overwhelming variations in inventory as triggered by the unpredictability of market demand of a particular product (Cannella \& Ciancimino, 2010). Typical consequences of the bullwhip effect include either stock-outs or over-stock situations in the supply chain, which have the further effect of complicating planning. The demand of inventory in the market is in turn associated with economic factors, such as whether there is a recession or there is prosperity (Tempelmeier, 2006). Notably, despite being adversely affected by the global economic recession that struck many developed and emerging market economies from around September 2008, a notable fact is that market dynamics and permutations (e.g. inventory demand) in South Africa were slowed down but were not reversed. This could be attributed to the fact that Africa as a whole has relatively weak global linkages (Bakrania \& Lucas, 2009). Therefore, although the country was affected by the global economic meltdown (Jacobs, 2009), demand for products in South Africa has remained stable such that most companies in the country have enjoyed consistent product demand which is in line with their forecasts (Mboweni, 2008).

Environmental concerns emerged as the second least important challenge. The results of the current study demonstrate that environmental concerns, such as the call for the implementation of green logistics, have little importance to SMEs in their implementation of logistics strategies. This is interesting, since the phrase 'Green logistics', which relates to the adoption of environmentally friendly logistics strategies, has captivated the world in the past few decades (Lin \& Ho, 2008). However, the findings of the study are consistent with previous research by Evangelista, Huge-Brodin, Isaksson and Sweeney (2011) which reveals that firm characteristics such as company size and the number of people employed are positively correlated to the adoption of green logistics. As such, SMEs, by virtue of their size, are unlikely to be early adopters of green logistics strategies. In agreement, Isaksson, Björklund, Evangelista, and Huge-Brodin (2011) also found greater aversion to the adoption green logistics among SMEs. Such aversion may be attributed to a constellation of factors that include the lack of economic resources, the lack of knowledge and experience, and a plethora of technical, information and managerial barriers, all which tend to overwhelm SMEs (Biondi, Frey \& Iraldo, 2000). Therefore, these factors compel SMEs to be least concerned with environmental issues. 
Benefits Derived From Implementing Logistics Strategies

Table 5 represents the findings from a cluster of questions dealing with the perceived benefits of implementing logistics strategies in SMES. The benefits have been placed in rank order, in accordance with the frequencies obtained in the study.

Table 5: Benefits of implementing logistics strategies

\begin{tabular}{|c|c|c|c|c|c|c|c|c|}
\hline \multirow[t]{2}{*}{ Benefits } & \multirow{2}{*}{$\begin{array}{l}\text { Valid } \\
n\end{array}$} & \multicolumn{6}{|c|}{ Benefit Rating } & \multirow{2}{*}{$\begin{array}{c}\text { Position } \\
\text { in rank } \\
\text { order }\end{array}$} \\
\hline & & $1(\%)$ & $2(\%)$ & $3(\%)$ & $4(\%)$ & $5(\%)$ & $6(\%)$ & \\
\hline $\begin{array}{l}\text { Gaining competitive } \\
\text { advantages }\end{array}$ & 131 & 3.82 & 1.53 & 7.63 & 16.79 & 25.95 & 44.27 & 1 \\
\hline Increased sales & 131 & 2.29 & 2.29 & 11.45 & 16.79 & 32.06 & 35.11 & 2 \\
\hline $\begin{array}{l}\text { Reduction in operational } \\
\text { costs }\end{array}$ & 131 & 4.62 & 3.08 & 8.46 & 19.23 & 32.31 & 32.31 & 3 \\
\hline Increased turnover & 131 & 1.54 & 1.54 & 6.15 & 17.69 & 32.31 & 40.77 & 4 \\
\hline Reduce inventory level & 131 & 3.15 & 0.79 & 10.24 & 20.47 & 32.28 & 33.07 & 5 \\
\hline $\begin{array}{l}\text { Reduce lead-time in } \\
\text { production }\end{array}$ & 131 & 0.77 & 3.08 & 5.38 & 13.08 & 24.62 & 53.08 & 6 \\
\hline $\begin{array}{l}\text { Resource planning and } \\
\text { cost-saving }\end{array}$ & 131 & 2.29 & 1.53 & 8.40 & 12.21 & 29.01 & 46.56 & 7 \\
\hline $\begin{array}{l}\text { Improved coordination in } \\
\text { departments }\end{array}$ & 131 & 4.62 & 1.54 & 6.15 & 18.46 & 30.00 & 39.23 & 8 \\
\hline $\begin{array}{l}\text { Increase in coordination } \\
\text { between suppliers }\end{array}$ & 131 & 1.53 & 2.29 & 7.63 & 9.92 & 35.88 & 42.75 & 9 \\
\hline $\begin{array}{l}\text { Increase in coordination } \\
\text { with customers }\end{array}$ & 131 & 0.76 & 1.53 & 5.34 & 13.74 & 32.06 & 46.56 & 10 \\
\hline Forecasting & 131 & 0.00 & 3.05 & 6.11 & 16.03 & 31.3 & 43.51 & 11 \\
\hline $\begin{array}{l}\text { Support of information } \\
\text { systems }\end{array}$ & 131 & 2.31 & 3.08 & 12.31 & 15.38 & 26.92 & 40.00 & 12 \\
\hline More accurate costing & 131 & 4.62 & 5.38 & 10.00 & 16.15 & 28.46 & 34.62 & 13 \\
\hline $\begin{array}{l}\text { Difference in actual \& } \\
\text { forecast demand }\end{array}$ & 131 & 4.62 & 4.62 & 16.15 & 20.77 & 23.08 & 30.77 & 14 \\
\hline $\begin{array}{l}\text { Frequent changes to } \\
\text { orders }\end{array}$ & 131 & 7.69 & 2.31 & 16.92 & 20.77 & 26.15 & 26.15 & 15 \\
\hline $\begin{array}{l}\text { Shorter manufacturing } \\
\text { lead-time }\end{array}$ & 131 & 6.20 & 4.65 & 6.98 & 17.83 & 31.78 & 32.56 & 16 \\
\hline $\begin{array}{l}\text { Customers' special } \\
\text { demands }\end{array}$ & 131 & 1.54 & 3.08 & 7.69 & 14.62 & 27.69 & 45.38 & 17 \\
\hline Customers' satisfaction & 131 & 1.53 & 0.76 & 3.82 & 11.45 & 19.85 & 62.60 & 18 \\
\hline $\begin{array}{l}\text { Improvement in } \\
\text { customers' service }\end{array}$ & 131 & 3.88 & 0.78 & 8.53 & 22.48 & 27.13 & 37.21 & 19 \\
\hline $\begin{array}{l}\text { Provides support in } \\
\text { achieving objectives }\end{array}$ & 131 & 3.82 & 0.76 & 3.82 & 16.79 & 32.06 & 42.75 & 20 \\
\hline $\begin{array}{l}\text { Quick response to } \\
\text { customer needs }\end{array}$ & 131 & 1.54 & 2.31 & 3.85 & 10.00 & 29.23 & 53.08 & 21 \\
\hline $\begin{array}{l}\text { Quick facilitation of the } \\
\text { business processes }\end{array}$ & 131 & 3.82 & 0.00 & 5.34 & 12.98 & 32.06 & 45.80 & 22 \\
\hline Uniqueness of the product & 131 & 3.05 & 3.82 & 6.87 & 14.50 & 29.77 & 41.98 & 23 \\
\hline $\begin{array}{l}\text { Anticipation of customer } \\
\text { needs }\end{array}$ & 131 & 1.54 & 2.31 & 6.15 & 13.85 & 33.85 & 42.31 & 24 \\
\hline Flexibility & 131 & 1.53 & 2.29 & 9.16 & 12.98 & 28.24 & 45.80 & 25 \\
\hline
\end{tabular}




\begin{tabular}{|l|l|l|l|l|l|l|l|l|}
\hline Ability to innovate & 131 & 1.53 & 0.76 & 5.34 & 9.92 & 31.3 & 51.15 & 26 \\
\hline Reduced labour turnover & 131 & 2.29 & 0.00 & 4.58 & 12.21 & 22.14 & 58.78 & 27 \\
\hline $\begin{array}{l}\text { Average percentage per } \\
\text { response }\end{array}$ & & 2.85 & 2.19 & 7.79 & 15.45 & 29.17 & 42.52 & \\
\hline KEY: 1 = Not important & 6=Very important & & & & & & \\
\hline
\end{tabular}

An analysis of the results of the study in terms of the benefits derived from implementing logistics strategies (Refer to Table 5) reveals that gaining competitive advantages, increased sales and a reduction in operational costs were the most important paybacks to SMEs. Reduced labour turnover and the ability to innovate occupied the two lowest quadrants in the matrix.

Competitive advantage occupied the highest position among the benefits derived from implementing logistics strategies. This result has congruence with Quayle's (2003) assertion that logistics has also become more prominent as a critical success factor in competitive advantage, since it can be used to outperform competitors in providing the right product to the right place at the right time. Logistics provides competitive advantage through an array of its associated areas that include quick response systems, efficient consumer response, cross docking, management of incoming raw materials, production, storing of finished goods, its delivery to the customer as well as after sales service (Gunasekaran, 2003). When an SME enterprise uses logistics as a competitive weapon in an effective manner, it is able to perform better than the competition (Uden, 2007). The findings of this study seem to suggest that most SMEs have realised this fact, and are therefore deriving sustainable competitive advantage from their logistics strategies.

The results of this study also reveal that increased sales were the second highest ranking benefit. This finding demonstrates that by implementing logistics strategies, SMEs experience increased sales, which they consider to be a very important benefit. This is important, since increased sales are an antecedent to increased profits, which is the very reason for existing in business (Ayyagari, Thorsten \& Demirgüc-Kunt, 2005). Logistics is responsible for the distribution of products, which ensures that products are timely delivered to the marketplace, where they can be easily accessed by the customer (Roslin \& Ismail, 2008). This could be most opportune to SMEs, chiefly because sales are the major driver of profit in most businesses, both large and small (Kotler \& Armstrong, 2010). Therefore, SMEs could employ logistics strategies as an instrument for enhancing their market share through accelerated sales.

In this study, the reduction of operational costs emerged as the third most important benefit attributable to the implementation of logistics strategies by SMEs. The fact that efficient logistics pushes down costs is well established. Besides increased sales, profit may also be increased by reducing operational costs (Ciumag \& Ciumag, 2010). For instance, optimisation of the logistics arm of procurement can enable an SME to achieve significant savings in costs (Zhao \& Tang, 2009). The same applies to other logistics activities. The rational is that if logistics costs are suppressed, the funds that have been saved are available to the company and may also be used to boost operational profits (Koovappadi, 2012). This principle is manifested through the Theory of Constraints (TOC), a concept aimed at ensuring organisational effectiveness and efficiency in supply chains through reducing costs rather than through increasing sales (Alexandre, 2009).

Reduction of labour turnover and increased innovation emerged as the lowest ranking benefits. This implies that SMEs have not been able to link any decreases in turnover of manpower to the implementation of logistics strategies. Consistently, Ugbam, Onwumere

www.sajesbm.com

Article no 166 
and Imo (2012) link labour turnover in SMEs to a consortium of work related, behavioral, and attitudinal factors, rather than to the adoption of logistics strategies. With regard to innovation, respondents gave innovation a 'less important' tag, which suggests that they did not link it to the implementation of logistics strategies. This finding, however, contradicts previous studies (McAdam, Stevenson \& Armstrong, 2000; Lai, 2007) which reveal that the adoption and implementation of logistics strategies by SMEs has a stimulus effect on innovation in the organisation.

\section{CONCLUSIONS AND RECOMMENDATIONS}

The purpose of the study was to investigate the challenges encountered as well as the benefits derived by SMEs from the implementation of logistics strategies. Although the findings of the study are not surprising, they provide extended evidence regarding the perceptions of SME owners and managers towards these challenges and benefits.

The study acknowledges the dominating influence and importance of four challenges namely, finance, skills shortages among logistics practitioners, high costs associated with information technology and rapid technological developments faced by SMEs in implementing logistics strategies. Inventory management complications and environmental concerns emerged as the least important challenges experienced by SMEs in implementing logistics strategies.

Increases in competitive advantage, increased sales and the reduction of operational costs emerged as the most important benefits that SMEs realise in implementing logistics strategies. However, the reduction of labour turnover and increases in innovation were the least important benefits to SMEs.

Based on the findings of the study, several recommendations can be made. To address the challenges related to financial capitalisation, SMEs could seek financial assistance from government initiatives such as the Black Business Supplier Development Program (BBSDP), a program run by the Department of Trade and Industry and is aimed at fast-tracking SMEs that show a good potential for growth into the mainstream economy (DTI, 2012). Further financial assistance could be accessed through collaborative efforts between the SMEs and their suppliers. As a remedy to the extensive skills shortages, SMEs could invest in sustained training and development programs aimed at enhancing the logistics-related skills of their workforce (Brum, 2010). To deal with the complications associated with technology, SMEs could ensure that technology issues are co-opted into strategic planning initiatives, such that they form part of the goals and vision of the enterprise (Gagnon \& Dragon, 1998). However, this can only be attained when SMEs have managed to obtain adequate financial assistance, since the adoption of technology also depends on the availability of financial resources. If implemented, these strategies will effectively assist SMEs to proactively deal with nagging challenges encountered during the implementation of logistics strategies.

\section{LIMITATIONS AND IMPLICATIONS FOR FURTHER RESEARCH}

Despite all efforts made by the researchers to eliminate any flaws related to the study, a few remain, of which some should be highlighted. First, the scope of the study was restricted to SMEs in Emfuleni Local Municipal only. As a result, care should be exercised in generalising the findings of the study to SMEs in other contexts. Second, it was not possible for the researchers to control how the respondents completed the questionnaires, since respondents completed the questionnaires at their own time and in the absence of the researchers. Greater accuracy could have been achieved if the questionnaires had been completed in the presence of the researchers.

www.sajesbm.com

Article no 166 
The study has implications for further research. Similar studies could be conducted using an amplified number of SMEs. Since this study was conducted using a quantitative approach, the results of the study could also be refined by using a mixed-method approach. Comparative studies using SMEs and large enterprises could be conducted which focus on the challenges and benefits associated with the implementation of logistics strategies.

\section{MANAGERIAL IMPLICATIONS}

This study has relevance in that it adds value to the knowledge of the challenges as well as the benefits of implementing logistics strategies by SMEs. Managers in SMEs can therefore allocate more resources to providing solutions to those challenges that emerged as most important in this study. The recommendations suggested in this study may also be adopted to ease the impact of these challenges on SMEs. Upon realising that the implementation of logistics strategies has a wide array of benefits as observed in this study, managers in SMEs may refocus, synchronise and positively adjust their logistics strategies in order to position their organisations to be recipients to these pertinent paybacks.

\section{REFERENCES}

Abonyi, G. (2005). Integrating SMEs into global and regional value chains: Implications for sub-regional cooperation in the Greater Mekong sub-region. Prepared for UNESCAP, Bangkok, Thailand.

Agapiou, A., Clausen, L.E., Flanagan, R. \& Norman, G. (1998). The role of logistics in the materials flow control process. Construction Management and Economics, 16,131-137.

Alexandre, L. (2009). Theory of constraints and the combinatorial complexity of the productmix decision. International Journal of Production Economics, 121(1), 121-129.

Anja, S., Thomas, B. \& Sascha, K. (2009). International entrepreneurship: Towards a theory of SME internationalization. Journal of International Business and Economics, 9(1), 1-12.

Arvis, J.F., Mustra, M.A., Panzer, J., Ojala, L, \& Naula, T. (2007). Connecting to compete: Trade logistics in the global economy. International Bank for Reconstruction and Development: The World Bank.

Ayyagari, M., Thorsten, B. \& Demirgüc-Kunt, A. (2005). Small and medium enterprises across the globe. World Bank Policy Research Working Paper 3127, World Bank, August, Washington, D.C. Available at: http://siteresources.worldbank.org/DEC/Resources/84797-1114437274304/SMEglobe.pdf. Accessed on 2013/04/08.

Bakrania, S. \& B. Lucas (2009): The impact of the financial crisis on conflict and state fragility in Sub-Saharan Africa, Governance and Social Development Resource Centre, Issues Paper. Available at: http://www.gsdrc.org/go/emerging-issues\#crisis. Accessed on 2013/04/07.

Benjaafar, S., Li, Y. \& Daskin, M. (2010). Carbon footprint and the management of supply chains: Insights from simple models. Available at: http://www.ie.umn.edu/faculty/ faculty/pdf/beyada-3-31-10.pdf. Accessed on 24/05/10. 
Bienstock, C.C., Royne, M.B., Sherrell, D. \& Stafford, T.F. (2007). An expanded model of logistics service quality: Incorporating logistics information technology. International Journal of Production Economics, 133, 205-222.

Biondi, V., Frey, M. \& Iraldo, F. (2000). Environmental management systems and SMEs motivations, opportunities and barriers related to EMAS and ISO 14001 implementation. Greener Management International Spring, 29, 55-69.

Bonney, J. (1994). Supply chain management: Treat it like a product. Journal of American Shipper, 36(2), 39-43.

Bozarth, C.C., Donald, P.W., Barbara, B.F. \& James, E.F. (2007). The impact of supply chain complexity on manufacturing plant performance. Journal of Operations Management, 27(1), 78-93.

Braunscheidel, M.J. \& Suresh, N.C. (2007). The organisational antecedents of a firm's supply chain agility for risk mitigation and response. Journal of Operations Management, 27(2), 119-140.

Brum, S. (2010). What impact does training have on employee commitment and employee turnover. Available at: http://www.uri.edu/research//rc/research/papers/Brum-

Commitment.pdf. Accessed on 2011/01/13.

Burke, R. (2006). Small business SMEs: Guide to running business. Thames and Hudson: Burke Publishing.

Burt, D., Petcavage, S. \& Pinkerton, R. (2010). Supply management. $8^{\text {th }}$ ed. Boston: McGraw-Hill.

Cannella, S. \& Ciancimino, E. (2010). On the bullwhip avoidance phase: supply chain collaboration and order smoothing. International Journal of Production Research, 48(22), 6739-6776.

Cant, M.C., Strydom, J.W., Jooste, C.I. \& Du plessis, P.J. (2006). Marketing management. 4th ed. Cape Town: Juta \& Co.

Chadha, B. (1994). Disequilibrium in the labour market in South Africa. IMF Working Paper. Washington. International Monetary Fund.

Chen, W.H. (1999). The manufacturing strategy and competitive priority of SMEs in Taiwan: A case survey. Asia Pacific Journal of Management, 16, 331-349.

Chin,T. A., Hamid, A.B.A., Raslia, A. \& Baharun, R. (2012). Adoption of supply chain management in SMEs. Procedia - Social and Behavioral Sciences 65, 614- 619

Chiware, E.R.T. \& Dick, A.L. (2008). The use of ICTs in Namibia's SMEs sector to access business information services. The Electronic Library, 26(2), 145-157.

Chopra, S. \& Meindl, P. (2010). Supply chain management, strategy, planning and operation. Upper Saddle River, New Jersey: Pearson.

Christopher, M. (1998). Logistics and supply chain management: Strategies for reducing costs and improving services. $2^{\text {nd }}$ ed. New York: Financial Times Management. 
Ciumag, A. \& Ciumag, M. (2010): Analysis of the relationship between cost, price and profit in lignite extraction. Published in: International Scientific Conference EcoTrend, VI-th edition. Available at: http://mpra.ub.uni-muenchen.de/30969/ Accessed on 2013/04/07.

Cocca, P. \& Alberti, M. (2010). A framework to assess performance measurement systems in SMEs. International Journal of Productivity and Performance Management, 59(2), 186200.

Copper, D. \& Schindler, P. (2011). Business research methods. $11^{\text {th }}$ ed. Boston. McGraw Hill.

Creswell, J.W. (2009). Research design: Qualitative, quantitative and mixed method approaches. London: Sage.

Damaskopoulos, P.\& Evgeniou, T. (2003). Adoption of new economy practices in SMEs in Eastern Europe. European Management Journal, 21 (2), 133-145.

Dekker, R., Bloemhof, J. \& Mallidis, I. (2012). Operations research for green logistics: An overview of aspects, issues, contributions and challenges. European Journal of Operational Research, 219, 671-679.

Department of Trade and Industry (the DTI) (2012). Black business supplier development programme. Available at:

http://www.services.gov.za/services/content/Home/OrganisationServices/businessincentives/ blackbusinesssupplier/en ZA. Accessed on 2012/11/07.

Deros, B.M., Yusof, S.M. \& Salleh, A.M. (2006). A benchmarking implementation framework for automotive manufacturing SMEs. International Journal of Benchmarking, 13(4), 396-430. Drew, S.A.W, \& Smith P.A.C. (1998). The new logistics management: Transformation through organisational learning. International Journal of Physical Distribution and Logistics Management, 28(10), 666-681.

DTI Report. (2004). Entrepreneurial empowerment, job creation and equity facilitated: An analysis of the evolution of public sector support for small enterprises in South Africa. Review of Ten Years of Small Business Support in South Africa 1994 - 2004. Available at: http://www.dti.gov.za/sme development/docs/10 year Review.pdf. Accessed on 2012/06/17.

Ebrahim, N. A., Ahmed, S. \& Taha, Z. (2008). R\&D networking and value creation in SMEs. Department of Engineering Design and Manufacture, Faculty of Engineering, University of Malaya, Kuala Lumpur.

Ellegaard, C. (2006). Small company purchasing: A research agenda. Journal of Purchasing \& Supply Management, 12, $272-283$.

Escriba-Esteve, A., Sanchez-Peinado, L. \& Sanchez-Peinado, E. (2009). The influence of top management teams in the strategic orientation and performance of small and mediumsized enterprises. British Journal of Management, 20, 581-597.

Evangelista, P., Huge-Brodin, M., Isaksson, K. \& Sweeney, E. (2011). The impact of 3PL's green initiatives on the purchasing of transport and logistics services: An exploratory study. Proceedings of the 20th Annual IPSERA Conference: "Vision 20/20 - Preparing today for

www.sajesbm.com

Article no 166 
tomorrow's challenges" 10th-13th April, Maastricht, the Netherlands.

Falkena, H. (2000). SMEs access to finance in South Africa: A supply side regulatory review.Report by the Task group of the Policy Board of Financial Services and Regulations. Cape Town: Kluwer Publishers.

Falkena, H., Abedian, I., Von-Blottnitz, M., Coovadia, C., Davel, G., Madungandaba, J., Masilela, E. \& Ree, S. (2010). SMEs access to finance in South Africa: a supply side regulatory review. Available at:

http://www.treasury.gov.za/publications/other/Access\%20to\%20Finance\%20in\%20South\%2 0Africa\%20-\%20A\%20Supply-Side\%20Regulatory\%20Review.pdf. Accessed on 20/03/2013.

Fawcett, S. E., Magnan, G. M. \& Mccarter, M. W (2008). Benefits, barriers, and bridges to effective supply chain management. Supply Chain Management: An International Journal, 13(1), 35 - 48.

Fouche, C.B. \& DE Vos, A.S. (2005). Problem formulation. In DE Vos, A.S., Strydom, H., Fouche, C.B. \& Delport C.S.L., ed. Research at Grass roots: For the social sciences and human service profession. 3rd ed. Pretoria: Van Schaik Publishers.

Gagnon,Y \& Dragon, J. (1998). The impact of technology on organizational performance. Journal of Public sector Management, 43(1), 19-31.

Gentle. J.A. (2008). Tips to become a logistics professional. Available at: http://www.logisticsmgmt.com/blog/640000464/post/560022456.html. Accessed on 2013/04/04.

Gelinas, R. \& Bigras, Y. (2004). The characteristics and features of SMEs: Favourable or unfavourable to logistics integration? Journal of Small Business Management, 42(3), 263278.

Gourova, E. (2010). Knowledge management strategy for small and medium enterprises. Proceedings of the International Conference on Applied Computer Science, 639-648.

Gunasekaran, A. (2003). The successful management of a small logistics company. International Journal of Physical Distribution \& Logistics Management, 33(9), 825-842.

Grant Thornton's International Business Report. (2012). Grant Thornton survey reveals overregulation is SA's biggest constraint to business expansion. Available at:

http://www.gt.co.za/News/Press-releases/International-businessreport/2012/ibrq4 2011.asp. Accessed on 2012/03/05.

Gravetter, F.J. \& Forzano, L.B. (2003). Research method for the behavioural sciences. Belmont: Wadsworth Thomson Learning.

Haan, J., Kisperska-moron, D. \& Placzek, E. (2007). Logistics management and firm size: A survey among Polish small and medium enterprises. International Journal of Production Economics, 108(1-2), 119-126.

Hagen, B., Zucchella, A., Cerchiello, P. \& De Giovanni, N. (2012). International strategy and performance: Clustering strategic types of SMEs. International Business Review 21, 369382. 
Hamisi, S. (2011). Challenges and opportunities of Tanzanian SMEs in adapting supply chain management. African Journal of Business Management, 5(4), 1266-1276.

Hendrickson, M. (2009). SME competitiveness in the Caribbean: Challenges and opportunities. ECLAC. Port of Spain Office.

Hendricks, K. \& Singhal, V.R (2005). The effect of supply chain disruptions on long-term shareholder value, profitability and share price volatility. The University of Western Ontario London, Ontario, Canada.

Heyns, G. \& Luke, R. (2012). Skills requirements in the supply chain industry in South Africa. Journal of Transport and Supply Chain Management, 2, 107-125.

Hill, J. \& Wright, L.T. (2001). A qualitative research agenda for small to medium-sized enterprises. Marketing Intelligence \& Planning, 19(6), 432-443.

Hong, P., \& Jeong, J. (2006). Supply chain management practices of SMEs: From a business growth perspective. Journal Enterprise Information Management, 19(3), 292-302.

Isaksson, K., Björklund, M., Evangelista, P \& Huge-Brodin, M. (2011). The challenge and adoption of green initiatives for transport and logistics service providers. Available at: liu.diva-portal.org/smash/get/diva2:476094/FULLTEXT01. Accessed on 2013/04/0 7.

Jacobs, P (2009): Questioning pro-poor responses to the global economic slump. Review of African Political Economy, 122(36), 194-217.

Karjalainen, K. \& Kemppainen, K. (2008). The involvement of small-and medium-size enterprises in public procurement: Impact of resource perceptions, electronic systems and enterprise size. Journal of Purchasing \& Supply Management, 14, 230-240.

Krajewski, L. J., Ritzman, L. P. \& Malhotra, M. K. (2010). Operations management. Processes and supply chains. $9^{\text {th }}$ ed. New York: Pearson.

Kruse, G. (2007). Cash is king - and don't you forget it. Journal of Operations Management, 33(6), 13-17.

Koskinen, P. \& Hilmola, O.P. (2008). Supply chain challenges of North-European paper industry. Journal of Industry Management \& Data Systems, 108(2), 208-227.

Kothari, C. R. (2008). Research methodology: Methods and techniques. $2^{\text {nd }}$ ed. New Delhi: New Age International.

Kotler, P. \& Armstrong, G. (2010). Principles of marketing. New Jersey. Prentice Hall.

Koovappadi, E. (2012). Logistics cost reduction: Best practices. Available at:

http://ezinearticles.com/?Logistics-Cost-Reduction---Best-Practices\&id=814237. Accessed on $2013 / 04 / 02$.

Kuthiala, K. (2003). E-commerce in India: challenges and choices. Journal of Services Research 2 (2), 139-155. 
Lai, R. S. (2007). Policy innovation of logistics for SMEs in Taiwan. The 34th International Small Business Congress, November 13, TAIWAN. Available at: http://www.isbc2007.org/isbc/upload/2879.pdf. Accessed on 2013/04/06.

Lasserre, F. (2004). Logistics and the internet: Transportation and location issues are crucial in the logistics chain. Journal of Transport Geography, 12, 73-84.

Levey, M. \& Powell, P. (2005). Strategies for growth in SMEs: The roles of information and information systems. Burlington: Oxford.

Lin C.Y. \& Ho, Y.H (2008). An empirical study on logistics service providers' intention to adopt green innovations. Journal of Technology Management \& Innovation, 3(1), 17-26.

Loecger, U. (2000). Small and medium-sized enterprises: Delimitation and the European definition in the area of industrial business. European Business Review, 12(5), 261-264.

Lukka, A. (2005). Evolution of logistics theory. Lappeenranta: Finland.

Malhotra, N. K. (2007). Marketing research: An applied orientation. $2^{\text {nd }}$ ed. New Jersey, Upper Saddle River: Prentice-Hall.

Malhotra, N. K. (2009). Marketing research: An applied orientation. $6^{\text {th }}$ ed. Eaglewood Cliffs, New Jersey: Prentice- Hall.

Malhotra, N. K. (2011). Basic marketing research. $4^{\text {rd }}$ ed. Eaglewood Cliffs, New Jersy: Prentice- Hall.

Maree, K. \& Pietersen, J. (2007). Surveys and the use of questionnaires. In MAREE, K., ed. First steps in research. Pretoria: Van Schaik Publishers.155-170.

Mbamba, U.O.L. (2009). The Technology Challenges in Procurement Management. 24th Materials Management Professionals' Annual Conference, December 1st-3rd, 2009, Arusha, Tanzania.

Mboweni, T.T. (2008). An Annus Horribilis? Address by Mr TT Mboweni, Governor of South African Reserve Bank at the Annual Dinner in honour of the Ambassadors and High

Commissioners accredited to the Republic of South Africa. Pretoria, 27 November 2008.

McAdam, R., Stevenson, P. \& Armstrong, G. (2000). Innovative change management in SMEs: beyond continuous improvement. Logistics Information Management, 13(3), 138-149.

MCkinnon, A. (2009).The present and future land requirements of logistical activities. Land Use Policy, 26, 293-301.

Mclvor. R. (2006). How the transaction cost and resource-based theories of the firm inform outsourcing evaluation. Journal of Operations Management, 27(1), 45-63.

Meade, L. \& Sarkis, J. (1998). Strategic analysis of logistics and supply chain management systems using the analytical network process. Logistics \& Transportation, 34(3), 201-215.

Musara, M. \& Olawale, F. (2012). Access to finance in the SME Sector: A South African perspective. Asian Journal of Business Management 4(1), 58-67. 
Mutula, S.M. \& BrakeL, P.V. (2006). E-readiness of SMEs in the ICT sector in Botswana with respect to information access. The Electronic Library, 24(3), 402-417

Napier, G., Serger, S.S. \& Hansson, E. W. (2004). Strengthening innovation and technology policies for SME development in Turkey: Opportunities for private sector involvement. Available at:

http://www.iked.org/pdf/Strengthening\%20Innovation\%20and\%20Technology\%20Policies\%2 0for\%20SME\%20Development\%20in\%20Turkey.pdf. Accessed on 2013/04/02.

Narasimhan, R. \& Talluri, S. (2009). Perspectives on risk management in supply chains. Journal of Operations Management, 27(2), 114-118.

Nepal, C., Karki, B.R. \& Niraula, K.P. (2006). Technology transfer in SMEs: Problems and issues in the context of Nepal. Available at:

http://www.unescap.org/tid/publication/indpub2306 chap3.pdf. Accessed on 2013/04/07.

Nielsen, A.E. \& Thomsen, C. (2009). CSR communication in small and medium-sized enterprises: A study of the attitudes and beliefs of middle managers. International Journal of Corporate Communications, 14(2), 176-189.

O'regan, N. \& Ghobadian, A. (2004).Testing the homogeneity of SMEs: The impact of size on managerial and organisational processes. European Business Review, 16(1), 64-67.

Oke, A., Burke, G. \& Myers, A. (2007).Innovation types and performance in growing UK SMEs. International Journal of Operations \& Production Management, 27(7), 735-753.

Overby, J.W. \& Servais, P. (2005). Small and medium-sized firms import behaviour: The case of Danish industrial purchasers. Journal of Industrial Marketing Management, 34, 7183.

Pasanen, M. \& Laukkanen, T. (2006). Team-managed growing SMEs: A distinct species? Management Research News, 29(11), 684-700.

Pittaway, L. \& Morrissey, B. (2004). Buyer-supplier relationships in small firms: The use of social factors to manage relationships. Lancaster University Management School Working Paper.

Polychronakis, Y \& Li, X. (2008). Barriers to international supply chain collaboration for small Chinese costume jewellery suppliers. Salford Business School, University of Salford, Manchester City, UK.

Quayle, M. (2003). A Study of supply chain management practice in UK industrial SMEs. Supply Chain Management: International Journal. 8(1), 79-86.

Raymond, L. \& Croteau, A.M. (2006). Enabling the strategic development of SMEs through advanced manufacturing systems: A configurational perspective. Industrial Management \& Data Systems, 106(7), 1012-1032.

Rogerson, C.M. (2008). Tracking SMME development in South Africa: Issues of finance, training and the Regulatory Environment. Arbon Forum, 19, 61-81.

Rogerson, C.M. (2000). Successful SMEs in South Africa: The case of clothing producers in the Witwatersrand. Development Southern Africa, 17(5), 687-716. 
Roslin, R. M. \& Ismail, N. (2008). Assessing competitive advantage of SMEs through effective supply chain management. Management Dynamics. 20(2), 74-91.

Ruiz-santos, C., Ruiz-mercader, J. \& Mcdonald, F. (2003). The use of contractual working time flexibility by Spanish SMEs. Personnel Review, 32(2), 164-186.

Sharp, L. (2011). South Africa's extraordinary skills shortage - Adcorp. Available at: http://www.politicsweb.co.za/politicsweb/view/politicsweb/en/page71619?oid=235542\&sn=D etail\&pid=71619. Accessed on 2012/03/05.

SImpson, M. \& Docherty, A.F. (2004). E-commerce adoption support and advice for UK SMEs. Journal of Small Business and Enterprise Development, 11(3), 315-328.

Soontiens, W. (2002). Managing international trade: An analysis of South Africa SMEs and regional exports. Management Decisions, 40(7), 710-719.

Strydom, H. (2005). Sampling and sampling methods. In DE VOS, A.S., Strydom, H., Fouche, C.B. \& Delport C.S.L., ed. Research at Grass roots: For the social sciences and human service profession. 3rd ed. Pretoria: Van Schaik Publishers. 192-204.

Talavera, O. \& D. Shafer, (2008). Entrepreneurs' gender and financial constraints: Evidence from international data. Journal of Computer Economics, 37(2), 270-286.

Tempelmeier, H. (2006). Inventory management in supply networks: problems, models, solutions. Norderstedt: Books on Demand.

Thakkar, J., Kanda, A. \& Deshmukh, S.G. (2008). Supply chain management in SMEs: Development of constructs and propositions. Asia Pacific Journal of Marketing \& Logistics, 20(1), 97-131.

Uden, L. (2007). How to promote competitive advantage for SMEs: Issues, ideas and innovation. Journal of Business systems, governance and ethics, 2(2), 1-15.

Udin, Z.M., Khan, M.K. \& Zairi, M. (2006). A collaborative supply chain management framework. Part 1 Planning Stage. Business Practice Management Journal. 1(5), 671-687.

Ugbam, O. C., Onwumere, J.U.J. \& Imo, G. (2012). The impact of labour turnover on survival of small and medium scale enterprises: Evidence from Nigeria. European Journal of Business and Management, 4(18), 187-213.

Vaaland, T.I. \& Heide, M. (2007). Can the SME survive the supply chain challenge? International Journal of Supply Chain Management, 12(1), 20-31.

Van der Vorst, J.G.A.J., Beulens, A.J.M. \& Van Beek, P. (2005). Innovations in logistics and ICT in food supply chain networks. In Jongen, W.M.F. \& Meulenberg, M.T.G., ed. Innovation in Agric-Food System. Wageningen: Wageningen Academic Publishers. 245-292.

Zacharia, Z.G. \& Mentzer, J.T. (2004). Logistics salience in a changing environment. Journal of Business Logistics, 25(1), 187-202.

Zacharia, Z.G. \& Mentzer, J.T. (2007). Role of logistics in new product development. Journal of Business Logistics, 28(1), 83-110. 
Zelealem, T.T. \& Pansiri, J. (2006). Perceive managerial problems in SMEs: Evidence from Botswana. Development \& Learning in Organizations, 20(5), 15-17.

Zeimpekis, V. \& Giaglis, G.M. (2006). Urban dynamic real-time distribution services: Insights from SMEs. Journal of Enterprise Information Management, 19(4), 367-388.

Zeithaml, V.A., Bitner, M.J., Gremler, D.D. \& Pandit, A. (2008). Service marketing: Integrating customer focus across the firm. $4^{\text {th }}$ ed. Tata McGraw-Hill: Publishing Company Limited.

Zhang, Q., Vonderembse, M.A. \& SU Lim, J. (2005). Logistics flexibility and its impact on customer satisfaction. International Journal of Logistics Management, 16(1), 71-95.

Zhao, X. \& Tang, Q. (2009). Analysis and strategy of the Chinese Logistics cost reduction. International Journal of Business and Management, 4(4), 188-191. 